\title{
Challenges and opportunities for creative-innovative clusters partnerships
}

\author{
Daniela Mihaela NEAMȚU \\ Stefan cel Mare University of Suceava, Romania \\ danan@seap.usv.ro \\ Ruxandra BEJINARU \\ Stefan cel Mare University of Suceava, Romania \\ ruxandrab@usm.ro \\ Cristian Valentin HAPENCIUC \\ Stefan cel Mare University of Suceava, Romania \\ valentinh@seap.usv.ro
}

\begin{abstract}
Clusters of innovation are global economic "hot spots" where new technologies germinate at an astounding rate and where pools of capital, expertise, and talent foster the development of new industries and new ways of doing business. They are vibrant, effervescent ecosystems composed of startups, businesses that support the startup process, and mature enterprises (many of whom evolved rapidly from a startup history). In these ecosystems, resources of people, capital, and know- how are fluidly mobile and the pace of transactions is driven by a relentless pursuit of opportunity, staged financing, and short business model cycles. The aim of this paper, clustering, which is an important model in the development of the countries and the concept of innovation have been reviewed together. The most prominent feature of the industry is to produce Technology. Countries to focus on knowledge-intensive industries and businesses as a result of regional cluster policies for innovation are seen that there is a relation between. Clustering is an important model for an innovational development in Romania. The analysis was carried out for a period of 3 years, for which there were registered the main achievements in the field of product innovation, processes, organizational forms and marketing methods, new or significantly improved, obtained by companies, starting from January 2016 until December 2018, representing Romania's contribution to the evaluation of the results of the European statistical research on innovation, 2018. Following the innovative activities in which the companies are engaged does the characterization of the innovation. The National Institute of Statistics provides the necessary means for carrying out statistical research on innovation in businesses in the business and industrial environment.
\end{abstract}

Keywords: Cluster, Innovative Clusters, Innovation in businesses, Industrial environment.

\section{Introduction}

Since the middle of the 20th century and up to now the main influence on the behavior of economies, actors and structures within them, was done through globalization (Genosko, 2006). Officials from the World Bank (2014) e.g. see under globalization "a growing interdependence of countries resulting from the increasing integration of trade, finance, people, and ideas in one global marketplace". That is why in order to make a clear link between developed theories and concepts leading to economic development of the territories understanding the origin and influence of globalization on current economic processes is very important. It is considered that the globalization was and has driven by dominantly changes in technological, economic, financial, institutional, political and socio-cultural environments. In such within the theories developed in the recent 20 years the concept of regional industrial clusters has received strong 
research focus and attention (Perlik \& Messerli, 2001; Boja, 2011; Genosko, 2006; Porter, 2000; World Bank,2009; Sölvell, 2008; Schätzl, 2001). From Porter (1998a) point of view under cluster the "geographically proximate group of interconnected companies and associated institutions in a particular field linked by companies and associated institutions" (Porter, 1998a, p. 199) can be seen.

At the early $90 \mathrm{~s}$ a special role has been dedicated to analysis of industrial spatial agglomerations and clusters. The results of these studies (Asheim et al, 2006; Asheim \& Gertler, 2005; Audretsch \& Feldman 1996; Bathelt \& Glückler, 2002; Feser, 1998; Christensen et al. 2012) show that clusters tend to indicate particular positive influence on the development of the territories. Malmberg and Power (2006), Wrobel (2008) and Blien and Maier (2008) say that it is often seen "as a synonymous with economic growth, jobs, innovations and synergies" (p.6) and is strongly associated with prosperity and wellbeing of territories as it offers conditions to produce innovation and competitiveness through actors interaction system in defined spatial proximity. Porter (1998b) also argues the connections that develop in cluster "are fundamental to competition, to productivity, and especially, to the direction and pace of new business formation and innovation" (Porter, 1998b, p. 205). Finally clusters much better align with the current needs of the company's business models. Creativity, knowledge (Bratianu \& Bejinaru, 2019; Bratianu \& Bejinaru, 2020; Bratianu et al., 2011) and innovation have become the main driving forces of regional economic, social and cultural development. Both in academic literature and in policy documents, creativity is considered essentially an urban phenomenon because human, economic and institutional resources are generally located in the big cities. Intangible resources should be considered as strategic resources because they constitute the intellectual capital of any organization (Bratianu, 2018; Bratianu \& Vatamanescu, 2017).

However, the attraction and retention of talent, namely of the creative class that mainly is represented by business studies graduates (Prelipcean \& Bejinaru, 2018), to small urban centers and rural areas could be a solution for their economic revitalization, reversing de-population and desertification trends (Hadad, 2018).

Such openness in the definition results in the attribution of clusters of different types depending on their structure, sizes, forms, industries, regions and countries (Porter, 1998b). Existence of such a variety of possible clusters can often lead to overlap with other agglomeration types and explains the blurriness of the concept. Unsurprisingly this has given rise to different cluster typologies, and in Table no. 1 we present a selection of these.

Table 1. Different typologies for cluster differentiation

\begin{tabular}{|l|l|l|}
\hline \multirow{2}{*}{ Gulati (1997) } & Modern urban cluster & Serve for metropolitan areas and export markets \\
\cline { 2 - 3 } Sandee (2002) & Artisanal rural cluster & Serve only rural/local demands \\
\hline \multirow{2}{*}{$\begin{array}{l}\text { Schmitz, Nadvi } \\
\text { (1999) }\end{array}$} & Dormant clusters & Production for only rural/local consumption \\
\hline \multirow{2}{*}{$\begin{array}{l}\text { Altenburg, Meyer- } \\
\text { Stamer } \\
(1999)\end{array}$} & Incipient clusters & Deep cooperation and will to enter global change \\
\cline { 2 - 3 } & Mature clusters & Production for global markets; vulnerable to global change \\
\cline { 2 - 3 } & $\begin{array}{l}\text { Advanced mass } \\
\text { production clusters }\end{array}$ & $\begin{array}{l}\text { Production is to serve the local market but there is the strong } \\
\text { external influence/competition }\end{array}$ \\
\cline { 2 - 3 } & $\begin{array}{l}\text { Cluster of transnational } \\
\text { corporations }\end{array}$ & $\begin{array}{l}\text { Based around foreign companies, which settle in particular } \\
\text { locations but have weak ties with local actors }\end{array}$ \\
\hline Duque, Rey (2008) & $\begin{array}{l}\text { Regional industry } \\
\text { clusters }\end{array}$ & $\begin{array}{l}\text { The spatial location of industries is the important characteristic; } \\
\text { Clusters whose elements share a common regional location, } \\
\text { where the region is defined as a metropolitan area, labor market, }\end{array}$ \\
\hline
\end{tabular}




\begin{tabular}{|l|l|l|}
\hline & & or other functional economic unit. \\
\cline { 2 - 4 } & Functional clusters & $\begin{array}{l}\text { Matters what companies produce; companies offering or } \\
\text { producing similar services or products belong to the same cluster }\end{array}$ \\
\cline { 2 - 4 } & $\begin{array}{l}\text { Value-added industry } \\
\text { clusters }\end{array}$ & $\begin{array}{l}\text { Focuses on products/services flows through companies, rather } \\
\text { than location or activity; ', a subset of industries of the economy } \\
\text { connected by flows of goods and services stronger than those } \\
\text { linking them to the other sectors of the national economy", }\end{array}$ \\
\hline
\end{tabular}

Source: authors elaboration.

PICBE | 1059

\section{European Strategic Cluster Partnerships and their importance}

In recent years, the importance of clusters as drivers of innovation has been recognized, enabling "open innovation" and the creation of new ideas through cooperation between companies and research institutions, mostly like universities (Bejinaru, 2017; Hapenciuc et al., 2016). As emphasized in the Europe 2020 Flagship Initiative Innovation Union, "internationally competitive clusters play a vital role in bringing together (...) large companies and SMEs, universities, research centers and communities of scientists and practitioners to exchange knowledge and ideas". In this context universities have multiple roles in managing the knowledge fluxes inside the clusters framework and to stimulate the transformation of knowledge inputs into knowledge outputs (Bejinaru \& Prelipcean, 2017; Bejinaru \& Iordache, 2010).

After a while due to intensive internationalization the competition between companies changed from being based on price to quality. More than ever the product / service started to be innovation and learning driven (Mackinnon \& Cumbers, 2007). In 1980 the research group "Groupe de Recherche Européen sur les Milieus Innovateurs" (GREMI School) started to discuss knowledge enhancing agglomeration, which was called "innovative milieu". They stressed the importance of socio-institutional aspects for economic activities and emphasized the significance of regional context for the enhancement of innovation and interaction between innovative economic actors (Benner, 2012; Bratianu et al., 2006; Dima et al., 2016; Dima et al., 2017). Although here the issue of proximity is very important, Genosko (2006) sees the concept of innovation milieu more as a cultural rather than geographical approach. In reference to Genosko (2006) innovation in innovative milieu is a collective process, which is based on the division of labour among big and small companies, private and public research and education institutions, suppliers and supporting organizations.

The concept of innovative cluster refers to the role of cluster into the learning network, understood as the "structure built to increase the level of knowledge and the participants' innovative capacity and to give the organizations the possibility of entering into relationships with other organizations and to support the voluntary learning of their employees" (Bessant \& Tsekouras in Passiante and Secundo, 2002). For this type of cluster OCDE (2001) uses the term of reduced form national innovation system, which can be interpreted as a replica of the entire system at the industrial cluster level or as an entity, which keeps the core elements of the national system. Bortagaray and Tiffin $(2005$, p.271) define the innovative cluster as "groups of firms, research centers and investors that work together within a narrow physical proximity in order to create new products, technologies and enterprises. They work into invisible relationship networks within a complex social framework where the collective industrial activity is based on learning and knowledge".

The two authors consider the innovative clusters a category of industrial clusters that can be divided into three subcategories, in accordance with the intensity of innovation, i.e.: innovative industrial clusters (centered on incremental innovations as the authors suggest, 
improvement of products, processes and routines), proto innovative clusters (focused on the latest knowledge as competitive means at global level, that supports a limited growth of the knowledge based firms but which lack all the elements to guarantee the medium-term development) and mature innovative clusters (developed inside the social community structure, which gather competitive international firms and path the rhythm and the direction of the world scientific and technological research). The model of the innovative cluster proposed by Bortagaray and Tiffin (2005) for the Latin America is presented in Table 2:

Table 2. Innovative cluster

\begin{tabular}{|c|c|c|}
\hline Elements & Contents & Description \\
\hline \multirow[t]{7}{*}{ Tangible } & $\begin{array}{l}\text { Knowledge based } \\
\text { firms }\end{array}$ & $\begin{array}{l}\text { The firms are those that store and generate knowledge, they assure an } \\
\text { appropriate framework for the learning process, they induce trust and } \\
\text { cooperation. The anchor firms are defined as "wide sources of technology, } \\
\text { markets and expertise". Beside them, there is a "swarm" of highly } \\
\text { innovative small firms, spinoffs, startups and big corporations, the last ones } \\
\text { being themselves innovation systems in miniature. }\end{array}$ \\
\hline & Knowledge inputs & $\begin{array}{l}\text { Universities, research-development laboratories, publications, expertise, } \\
\text { other sources. }\end{array}$ \\
\hline & $\begin{array}{l}\text { Consulting } \\
\text { services }\end{array}$ & $\begin{array}{l}\text { Firms specialized in technology transfer, legal services (brands, patents), } \\
\text { accounting firms, industrial design firms, industrial engineering firms, } \\
\text { marketing firms, patronal associations. }\end{array}$ \\
\hline & Specialized input & Specific or to be adapted materials, instruments, equipment. \\
\hline & Markets & $\begin{array}{l}\text { Sophisticated customers, the government-consumer, tenderers, transport } \\
\text { and communication networks for the world customers. }\end{array}$ \\
\hline & Cluster support & $\begin{array}{l}\text { Existence of public and private organizations to manage the network, to } \\
\text { promote it, to assure coordination (a kind of turntable plate of the cluster). } \\
\text { The business incubators are also rated as support organizations. }\end{array}$ \\
\hline & Financing & $\begin{array}{l}\text { Capital, risk capital and knowledge based banks with highly local } \\
\text { character. }\end{array}$ \\
\hline \multirow[t]{3}{*}{ Intangible } & Culture & $\begin{array}{l}\text { Favorable social climate: local cultural values, the contractors' value } \\
\text { system, the business and socio-cultural environment, the legal framework. }\end{array}$ \\
\hline & Integration & $\begin{array}{l}\text { Formal and informal links and interactions within individuals and } \\
\text { organizations. }\end{array}$ \\
\hline & Life quality & $\begin{array}{l}\text { Quality of life for the persons who work into community where the clusters } \\
\text { operate, measured through the cost of house, leisure facilities, quality } \\
\text { schools and hospitals, urban services and so on. }\end{array}$ \\
\hline
\end{tabular}

Source: Adaptation after Bortagaray and Tiffin (2005), p.73-79.

\section{Methodology}

In the European Union there has been a debate regarding clusters for almost two decades, however they represent a relatively new and almost unknown domain in some areas. The champion of the development of innovative clusters in Romania (except the capital) - what they represented before the emergence of new technologies - professional associations - is, without a doubt, Cluj County. Here, too, operate the only three clusters with the highest European qualification, "Golden Label" in Romania: AgroTransilvania Cluster, Transilvan Furniture Cluster and ITech Transilvania. The direction of the knowledge economy in the European Union and in the world is the direction of innovative digital hubs (Neamtu et al., 2019). The main difference consists in attracting in the hubs several fields of activity, and not the specialization on a certain domain, these digital innovation hubs representing, according to the executive director of Transylvania IT Cluster, Bianca Muntean (designated the cluster manager of the in the 
European Union), "the backbone around which all financial support measures from the 20212027 programming period will be built on the Digital Europe and Horizon Europe program".

\section{Results and discussions}

Currently, in the North-East Region, seven clusters are active, specialized in: imagistic medicine (Imago-Mol Iași), garments-knitwear-textiles (ASTRICO North-East), tourism (Bucovina Tourism Association), IT (New-Media ICONIC Iași), agri-food technologies (Ind-Agro-Pol), IT\&C (EURONEST IT\&C Hub, Iași), biotechnology (bioROne), constructions (Iasi Builders' Guild). The statistical data, as they are available on the website of the Northeast Regional Development Agency, are summarized in table 3.

These totaled about 200 members, with a total turnover of 429.7 million euros (at the level of 2017) and have as partners among local bodies and universities:

1. "Gheorghe Asachi" Technical University Iași;

2. "Grigore T. Popa" University of Medicine and Pharmacy, Iași;

3. The University "A.I. Cuza", Iasi;

4. Iasi County Council;

5. "Stefan cel Mare" University of Suceava (member of IT\&C EuroNest, IT \& HUB and APT Bucovina);

6. Suceava Chamber of Commerce and Industry;

7. Suceava County Council.

For comparison, only Transylvania IT Cluster has more than 100 organizations (economic agents, two universities, a research institute, two local / governmental bodies, a business center and a development association) and provides services in about 30 areas (eGovernment, IT, insurance, pharmaceutical, banking \& finance, health, energy, logistics, education, solutions for smart cities, telecommunications, etc.)

The North-East region provides, from this point of view, a huge potential for development, following the successful model of clusters in the North-West region, and the development of innovative clusters or hubs can be shaped even around industrial parks, as the one from Miroslava (with a 100\% occupancy degree, a real success) or the one planned to be built near "Stefan cel Mare" Suceava International Airport. The concentration of economic actors and expertise can be a suitable ground for any human resources consulting company, in its effort not only to survive in a market not just dynamic, as in Suceava County, but also to develop as a real intermediary between supply and demand (Bejinaru \& Hapenciuc, 2016).

Statistical research on innovation is also analyzed in territorial profile, at the level of regional development, the companies being selected in the sample by their headquarters (where they have their address). The analysis of the results is done both for all enterprises and only for small and medium-sized enterprises (SMEs), which highlights the best innovation at regional level. Thus, in the period 2016-2018, the highest weights were registered in the South-East Region 16.9\% and the North-East Region 13.8\%, and the lowest weights were in the South Muntenia Region 4.2\% and Southwest Oltenia 3.2\%. The highest shares of innovative companies only in products and / or processes were found in the South-East Region, 7.4\%, and the lowest in the West Region, $0.7 \%$. 
Table 3. Clusters in the North-East Region

\begin{tabular}{|c|c|c|c|c|c|c|}
\hline $\begin{array}{l}\text { Year of } \\
\text { establishment } \\
\text { and Name }\end{array}$ & $\begin{array}{l}\text { Number of } \\
\text { members } \\
\text { in the } \\
\text { cluster } \\
\text { and } \\
\text { employees } \\
\end{array}$ & \begin{tabular}{|l} 
Annual \\
turnover \\
(cluster \\
members)
\end{tabular} & \begin{tabular}{|l|} 
R\&D \\
rate / \\
cluster \\
members
\end{tabular} & $\begin{array}{l}\text { The main } \\
\text { objective of } \\
\text { the cluster }\end{array}$ & $\begin{array}{l}\text { Basic activities of the } \\
\text { cluster: }\end{array}$ & $\begin{array}{l}\text { Member } \\
\text { Universities }\end{array}$ \\
\hline $\begin{array}{l}2001 \text { - The } \\
\text { Association for } \\
\text { Tourism } \\
\text { Bucovina } \\
\\
\text { Region: N-E } \\
\text { Headquarters: } \\
\text { Suceava }\end{array}$ & $39 / 610$ & $\begin{array}{l}3,3 \text { mil. } \\
\text { Euro }\end{array}$ & -1 & $\begin{array}{l}\text { Improving the } \\
\text { quality of } \\
\text { tourism in } \\
\text { North-East } \\
\text { Romania }\end{array}$ & $\begin{array}{l}\text { Development of new } \\
\text { tourism products } \\
\text { Supporting the strategic } \\
\text { development of this } \\
\text { sector } \\
\text { Development } \\
\text { promotional materials } \\
\text { Training for tourism } \\
\text { personnel } \\
\text { International exchange of } \\
\text { good practices in the } \\
\text { context of European } \\
\text { projects }\end{array}$ & $\begin{array}{l}\text { "Stefan cel Mare" } \\
\text { University Suceava } \\
\text { (founding member) }\end{array}$ \\
\hline $\begin{array}{l}2010 \text { - Astrico } \\
\text { North East } \\
\text { Textile Cluster } \\
\\
\text { Region: N-E } \\
\text { Headquarters: } \\
\text { Savinesti } \\
\text { (Neamț County) }\end{array}$ & $30 / 1860$ & $\begin{array}{l}85 \text { mil. } \\
\text { Euro }\end{array}$ & $1 \%$ & $\begin{array}{l}\text { Internationaliz } \\
\text { ation of } \\
\text { companies } \\
\text { (export, etc.) }\end{array}$ & $\begin{array}{l}\text { Promoting and supporting } \\
\text { the development of the } \\
\text { textile industry in North- } \\
\text { East Romania. } \\
\text { Collaboration between } \\
\text { the members of the } \\
\text { cluster for establishing } \\
\text { contacts with new clients. } \\
\text { Development of joint } \\
\text { projects for new products. } \\
\text { Joint organization of } \\
\text { participation } \\
\text { specialized events such as } \\
\text { economic missions and } \\
\text { fairs. } \\
\text { Active involvement in the } \\
\text { training of the labor } \\
\text { force. } \\
\text { Date }\end{array}$ & $\begin{array}{l}\text { The Faculty of } \\
\text { Textiles, Leather } \\
\text { and Industrial } \\
\text { Management of the } \\
\text { Technical } \\
\text { University } \\
\text { «Gheorghe Asachi» } \\
\text { Iaşi }\end{array}$ \\
\hline $\begin{array}{l}2011 \text { - bioROne } \\
\text { - cluster in } \\
\text { biotechnology } \\
\text { Region: N-E } \\
\text { Headquarters: } \\
\text { Iasi }\end{array}$ & $13 / 1609$ & $\begin{array}{l}72 \text { mil. } \\
\text { euro }\end{array}$ & $<1 \%$ & $\begin{array}{l}\text { Increasing the } \\
\text { innovative } \\
\text { capacity of the } \\
\text { regional } \\
\text { economy }\end{array}$ & $\begin{array}{l}\text { Networking activities and } \\
\text { international relations, } \\
\text { Transfer of know-how } \\
\text { Lobby, Transposition of } \\
\text { the innovative culture in } \\
\text { the economy, Support for } \\
\text { financing opportunities } \\
\text { and programs, Research } \\
\text { and development of the } \\
\text { good quality human } \\
\text { resource in the region }\end{array}$ & $\begin{array}{l}\text { National Institute } \\
\text { for Research and } \\
\text { Development for } \\
\text { Textiles and } \\
\text { Leather, Bucharest }\end{array}$ \\
\hline
\end{tabular}

PICBE $\mid 1062$ 


\begin{tabular}{|c|c|c|c|c|c|c|}
\hline \begin{tabular}{|l|}
$2013-$ \\
Innovative \\
Regional \\
Cluster \\
EURONEST \\
IT\&C HUB \\
Region: N-E \\
Headquarters: \\
Iasi \\
\end{tabular} & $21 / 447$ & $\begin{array}{l}21,6 \text { mil. } \\
\text { Euro }\end{array}$ & $5 \%$ & \begin{tabular}{|l|} 
Increasing the \\
innovative \\
capacity of the \\
regional \\
economy
\end{tabular} & $\begin{array}{l}\text { Networking activities and } \\
\text { international relations } \\
\text { Easier access to training } \\
\text { Transfer of know-how, } \\
\text { Lobby }\end{array}$ & Unavailable data \\
\hline $\begin{array}{l}2012 \text { - ICONIC } \\
\text { Region: N-E } \\
\text { Headquarters: } \\
\text { Iasi }\end{array}$ & $23 / 200$ & 1 mil euro & $2,5 \%$ & $\begin{array}{l}\text { Increasing the } \\
\text { innovative } \\
\text { capacity of the } \\
\text { regional } \\
\text { economy } \\
\end{array}$ & $\begin{array}{l}\text { Networking activities and } \\
\text { international relations } \\
\text { Easier access to training } \\
\text { Transfer of know-how, } \\
\text { Lobby }\end{array}$ & $\begin{array}{l}\text { "Gheorghe Asachi" } \\
\text { Technical } \\
\text { University, Iași } \\
\text { "A.I. Cuza" } \\
\text { University, Iași }\end{array}$ \\
\hline $\begin{array}{l}\text { 2012 - IMAGO- } \\
\text { MOL } \\
\text { Region: N-E } \\
\text { Headquarters: } \\
\text { Iasi }\end{array}$ & $8 / 29$ & $\begin{array}{l}0,78 \mathrm{mil} \\
\text { euro }\end{array}$ & $25 \%$ & $\begin{array}{l}\text { Increasing the } \\
\text { innovative } \\
\text { capacity of the } \\
\text { regional } \\
\text { economy }\end{array}$ & $\begin{array}{l}\text { Develop a strategic action } \\
\text { plan to support the } \\
\text { competitive development } \\
\text { of the medical imaging } \\
\text { sector in the North-East } \\
\text { Region. }\end{array}$ & $\begin{array}{l}\text { "Grigore T. Popa" } \\
\text { University of } \\
\text { Medicine and } \\
\text { Pharmacy, Iaşi }\end{array}$ \\
\hline \begin{tabular}{|l|}
2011 - IND- \\
AGRO-POLE \\
Region: national \\
Headquarters: \\
Iasi
\end{tabular} & $100 / 700$ & $\begin{array}{l}164 \text { mil. } \\
\text { Euro }\end{array}$ & $3 \%$ & $\begin{array}{l}\text { Increasing the } \\
\text { innovative } \\
\text { capacity of the } \\
\text { regional } \\
\text { economy }\end{array}$ & $\begin{array}{l}\text { Cooperation, Research, } \\
\text { Development, Innovation } \\
\text { Training, Marketing and } \\
\text { Public Relations } \\
\text { Networking and } \\
\text { internationalization }\end{array}$ & $\begin{array}{l}\text { University of } \\
\text { Agricultural } \\
\text { Sciences and } \\
\text { Veterinary } \\
\text { Medicine, Iasi }\end{array}$ \\
\hline $\begin{array}{l}2013 \text { - Guild of } \\
\text { Builders from } \\
\text { Iasi } \\
\text { Region: N-E } \\
\text { Headquarters: } \\
\text { Iasi }\end{array}$ & $23 / 1845$ & 82 mil euro & - & $\begin{array}{l}\text { Platform for } \\
\text { collaboration, } \\
\text { development, } \\
\text { research and } \\
\text { innovation in } \\
\text { the civil and } \\
\text { individual } \\
\text { construction } \\
\text { industry. }\end{array}$ & $\begin{array}{l}\text { Improvement of the } \\
\text { quality of } \\
\text { construction the } \\
\text { carried out in Iasi county; } \\
\text { Increasing } \\
\text { standards quality } \\
\text { transparency in the field; } \\
\text { Improving the image of } \\
\text { Iasi builders in relation to } \\
\text { local authorities and } \\
\text { public opinion; Offering } \\
\text { information and solutions } \\
\text { regarding business } \\
\text { opportunities in the field; } \\
\text { Developing the } \\
\text { businesses of the member } \\
\text { companies in the cluster } \\
\text { and increasing their } \\
\text { competitiveness } \\
\text { national and international } \\
\text { level. }\end{array}$ & $\begin{array}{l}\text { "Gheorghe Asachi" } \\
\text { Technical } \\
\text { University, Iași }\end{array}$ \\
\hline
\end{tabular}

PICBE $\mid 1063$

Source: authors elaboration. 


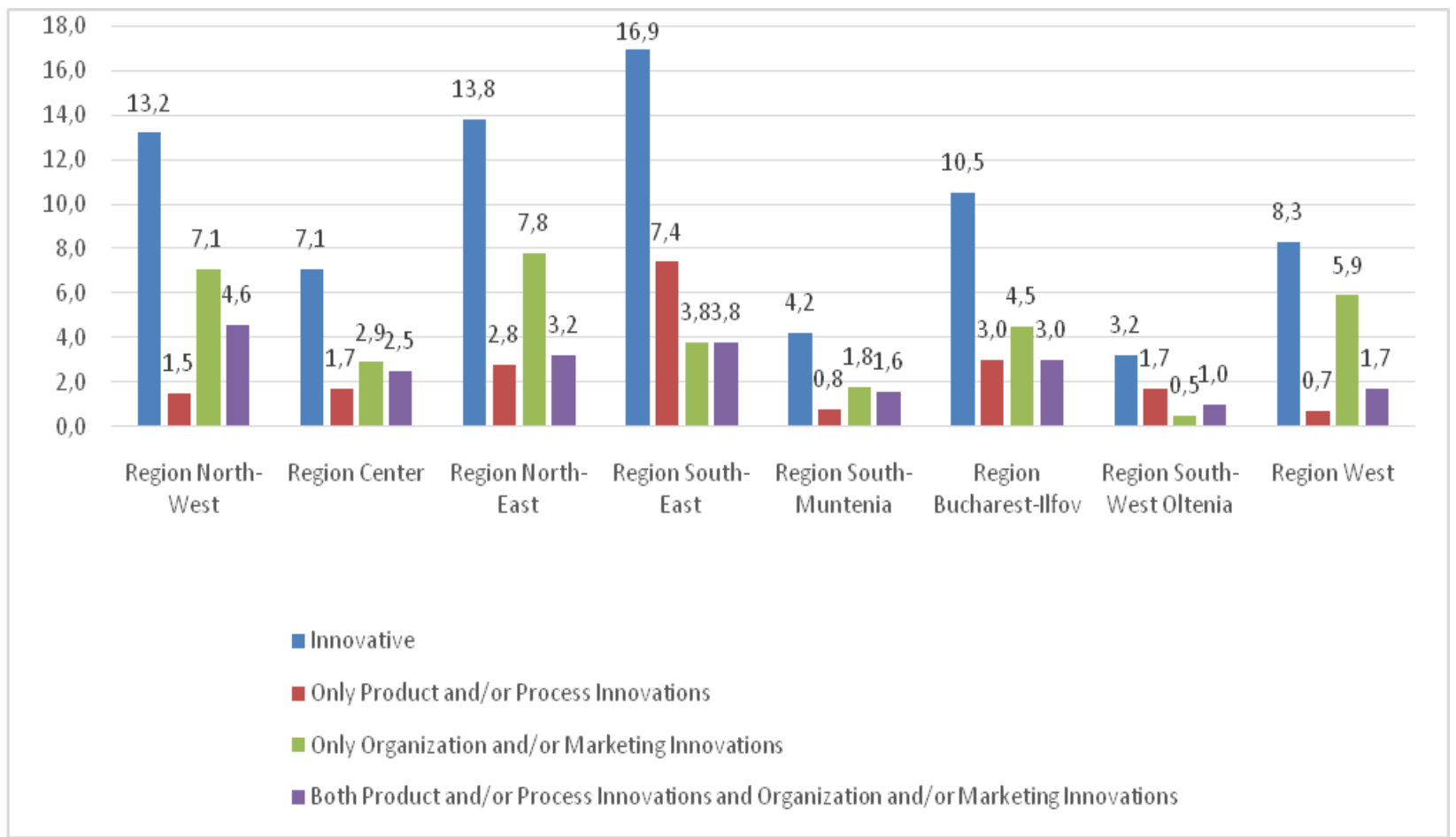

Figure 1. Share of enterprises, in total enterprises, by types of innovations, in territorial profile, between 2016-2018

Source: Authors' own research.

The North-East region had the most enterprises with innovations of organizational and/or marketing forms, $7.8 \%$ and the smaller South-West Oltenia Region 0.5\%. In the North-West Region, most enterprises were highlighted with both product and / or process innovations and with $4.6 \%$ organizational and / or marketing innovations, the fewest being registered in the South-West Oltenia Region, $1.0 \%$. In the economic sectors, the same regions had the highest shares. Thus, in the industry sector $17.9 \%$ of enterprises were innovative in the South-East Region and $13.0 \%$ in the North-West Region, and in the services sector $15.6 \%$ of enterprises were innovative in the South-East Region and 15, 5\% in the North-East Region. The highest percentages of innovative SMEs were registered in the South-East Region $16.3 \%$ and in the North-East Region 13.6\%. The least innovative SMEs were in the South-West Oltenia Region $(3.2 \%)$.

In the South-East Region there were the most innovative SMEs of products $(4.8 \%)$ and processes $(8.0 \%)$, and in the North-West Region, the most innovative SMEs of organization methods $(10.0 \%)$ and marketing methods $(9.1 \%)$. In the North-East Region, are located the highest share of innovative SMEs (3.4\%) that received public funding. The SMEs that cooperated the most in carrying out innovative activities were $2.6 \%$ in the North-West Region. In the SouthEast Region there were the most innovative SMEs of new products for the enterprise $2.0 \%$ and in the Bucharest-Ilfov Region there were the most innovative SMEs of new products on the market $0.6 \%$. 
Table 4a. TOP 5 - the most innovative activities of SMEs, in territorial profile, between 2016-2018

\begin{tabular}{|c|c|c|c|c|c|c|c|c|}
\hline Top & \multicolumn{2}{|c|}{ North-West } & \multicolumn{2}{|l|}{ Centre } & \multicolumn{2}{|c|}{ North-East } & \multicolumn{2}{|l|}{ South-East } \\
\hline & Activities & $\%$ & Activities & $\%$ & Activities & $\%$ & Activities & $\%$ \\
\hline 1 & Editing activities & 47,9 & $\begin{array}{l}\text { Manufacture of } \\
\text { basic } \\
\text { pharmaceuticals } \\
\text { and } \\
\text { pharmaceutical } \\
\text { preparations }\end{array}$ & 28,6 & $\begin{array}{l}\text { Research } \\
\text { and } \\
\text { Developm } \\
\text { ent }\end{array}$ & 100,0 & Air transport & 100,0 \\
\hline 2 & $\begin{array}{l}\text { Manufacture of } \\
\text { substances and } \\
\text { chemicals }\end{array}$ & 41,4 & $\begin{array}{l}\text { Postal and } \\
\text { courier activities }\end{array}$ & 28,6 & $\begin{array}{l}\text { Service } \\
\text { activities } \\
\text { and } \\
\text { informatio } \\
\mathrm{n} \\
\text { technolog } \\
\mathrm{y}\end{array}$ & 64,8 & $\begin{array}{l}\text { Supply of steam } \\
\text { and air } \\
\text { conditioning }\end{array}$ & 57,1 \\
\hline 3 & $\begin{array}{l}\text { Research and } \\
\text { Development }\end{array}$ & 26,6 & $\begin{array}{l}\text { Other industrial } \\
\text { activities }\end{array}$ & 28,3 & $\begin{array}{l}\text { Manufactu } \\
\text { re of } \\
\text { computers } \\
\text { and } \\
\text { electronic } \\
\text { and } \\
\text { optical } \\
\text { products }\end{array}$ & 42,9 & $\begin{array}{l}\text { Architectural } \\
\text { and engineering } \\
\text { activities; } \\
\text { technical } \\
\text { analysis }\end{array}$ & 50,0 \\
\hline 4 & $\begin{array}{l}\text { Wood processing, } \\
\text { manufacture of } \\
\text { wood and cork } \\
\text { products, except } \\
\text { furniture }\end{array}$ & 23,5 & $\begin{array}{l}\text { Manufacture of } \\
\text { clothing }\end{array}$ & 27,1 & $\begin{array}{l}\text { Manufactu } \\
\text { re of } \\
\text { electrical } \\
\text { equipment }\end{array}$ & 35,0 & $\begin{array}{l}\text { Manufacture of } \\
\text { textile products }\end{array}$ & 45,0 \\
\hline 5 & $\begin{array}{l}\text { Industry of metal } \\
\text { constructions and } \\
\text { metal products, } \\
\text { excluding } \\
\text { machines, } \\
\text { machines and } \\
\text { installations }\end{array}$ & 27,6 & $\begin{array}{l}\text { Manufacture of } \\
\text { other means of } \\
\text { transport }\end{array}$ & 23,5 & $\begin{array}{l}\text { Manufactu } \\
\text { re of } \\
\text { beverages }\end{array}$ & 33,3 & $\begin{array}{l}\text { Manufacture of } \\
\text { substances and } \\
\text { chemicals }\end{array}$ & 44,4 \\
\hline
\end{tabular}

Source: authors elaboration.

Table 4b. TOP 5 - the most innovative activities of SMEs, in territorial profile, between 2016-2018

\begin{tabular}{|c|c|c|c|c|c|c|c|c|}
\hline Top & \multicolumn{2}{|c|}{ South-Muntenia } & \multicolumn{2}{|c|}{ Bucharest-Ilfov } & \multicolumn{2}{|c|}{ South-West Oltenia } & \multicolumn{2}{|l|}{ West } \\
\hline & Activities & $\%$ & Activities & $\%$ & Activities & $\%$ & Activities & $\%$ \\
\hline 1 & $\begin{array}{l}\text { Service activities } \\
\text { in information } \\
\text { technology }\end{array}$ & 45,2 & $\begin{array}{l}\text { Decontamination } \\
\text { activities and } \\
\text { services }\end{array}$ & 50,0 & $\begin{array}{l}\text { Storage and } \\
\text { ancillary } \\
\text { activities for } \\
\text { transportation }\end{array}$ & 17,6 & $\begin{array}{l}\text { Metallurgical } \\
\text { industry }\end{array}$ & 71,4 \\
\hline 2 & $\begin{array}{l}\text { Other industrial } \\
\text { activities }\end{array}$ & 35,0 & $\begin{array}{l}\text { Tanning and } \\
\text { finishing } \\
\text { leathers, } \\
\text { manufacture of } \\
\text { travel and } \\
\text { leather goods; } \\
\text { fur preparation } \\
\text { and dyeing }\end{array}$ & 27,2 & $\begin{array}{l}\text { Editing } \\
\text { activities }\end{array}$ & 15,4 & $\begin{array}{l}\text { Manufacture of } \\
\text { other means of } \\
\text { transport }\end{array}$ & 35,3 \\
\hline
\end{tabular}




\begin{tabular}{|c|c|c|c|c|c|c|c|c|}
\hline 3 & $\begin{array}{l}\text { Manufacture of } \\
\text { basic } \\
\text { pharmaceuticals } \\
\text { and } \\
\text { pharmaceutical } \\
\text { preparations }\end{array}$ & 28,6 & $\begin{array}{l}\text { Industry of metal } \\
\text { constructions } \\
\text { and metal } \\
\text { products, } \\
\text { excluding } \\
\text { machines, } \\
\text { machines and } \\
\text { installations }\end{array}$ & 26,0 & $\begin{array}{l}\text { Industry of } \\
\text { metal } \\
\text { constructions } \\
\text { and metal } \\
\text { products, } \\
\text { excluding } \\
\text { machines, } \\
\text { machines and } \\
\text { installations }\end{array}$ & 13,9 & $\begin{array}{l}\text { Gas production, } \\
\text { distribution of } \\
\text { gaseous fuels } \\
\text { through pipes }\end{array}$ & 33,3 \\
\hline 4 & $\begin{array}{ll}\text { Research } & \text { and } \\
\text { Development } & \end{array}$ & 28,6 & $\begin{array}{l}\text { Service activities } \\
\text { in information } \\
\text { technology }\end{array}$ & 25,7 & Food industry & 12,9 & $\begin{array}{l}\text { Manufacture of } \\
\text { basic } \\
\text { pharmaceuticals } \\
\text { and } \\
\text { pharmaceutical } \\
\text { preparations }\end{array}$ & 25,0 \\
\hline 5 & $\begin{array}{l}\text { Printing and } \\
\text { reproduction on } \\
\text { record of media }\end{array}$ & 25,0 & $\begin{array}{l}\text { Wood } \\
\text { processing, } \\
\text { manufacture of } \\
\text { wood and cork } \\
\text { products, except } \\
\text { furniture }\end{array}$ & 24,3 & $\begin{array}{l}\text { Manufacture } \\
\text { of machinery } \\
\text { and } \\
\text { equipment }\end{array}$ & 12,5 & $\begin{array}{l}\text { Manufacture of } \\
\text { substances and } \\
\text { chemicals }\end{array}$ & 23,5 \\
\hline
\end{tabular}

Source: authors elaboration.

From the data of the statistical research for the period 2014-2016, the top of the first 5 innovative economic activities of the SMEs, can be traced in the tables4a and $4 \mathrm{~b}$. The most innovative economic activities in which SMEs operate were as follows: in the North-West Region, publishing activity $47.9 \%$, in the Central Region, manufacturing of basic pharmaceuticals and pharmaceuticals 28.6\%, in the North Region - East, the research and development activity $100.0 \%$, in the South-East Region, air transport $100.0 \%$, in the SouthMuntenia region, services activities in information technology $46.2 \%$, in the Bucharest-Ilfov Region, activities and decontamination services 50.0\%, in the South-West Oltenia Region, storage and ancillary activities for transport $17.6 \%$ and in the West Region, the metallurgical industry $71.4 \%$.

Regarding the cooperation or active participation of the enterprise with other companies or institutions, in innovative activities, at the level of Romania, we summarize the following: during 2016-2018, 17.9\% of the total innovative companies of products and / or processes had agreements cooperation in realizing their innovations. Better cooperation is observed among large companies, $23.3 \%$ of their total cooperated.

The main cooperation partners of the innovative companies were suppliers of equipment, materials, components or software $9.3 \%$ and customers or buyers in the private sector $7.7 \%$. In economic sectors, the industry sector cooperates more than in the services sector.

Table 5. Share of the companies involved in cooperation, by size classes, activities and types of partners, in the period 2016-2018, \%

\begin{tabular}{|l|l|l|l|l|l|l|}
\hline Partner type & \multicolumn{3}{|c|}{ Companies } & \multicolumn{3}{|c|}{ Activities } \\
\cline { 2 - 8 } & Total & Small & $\begin{array}{l}\text { Mediu } \\
\mathrm{m}\end{array}$ & Large & Industry & $\begin{array}{l}\text { Service } \\
\mathrm{s}\end{array}$ \\
\hline Any kind of cooperation & 17,9 & 18,6 & 13,8 & 13,3 & 21,8 & 13,8 \\
\hline Other companies within the group & 3,0 & 2,2 & 2,5 & 12,1 & 4.0 & 2.0 \\
\hline Suppliers of equipment, component or software & 9,3 & 7,9 & 11,5 & 16,6 & 8,6 & 10,1 \\
\hline
\end{tabular}




\begin{tabular}{|l|l|l|l|l|l|l|}
\hline Customers or buyers in the public sector & 2,4 & 2,0 & 2,2 & 6,3 & 1,5 & 3,2 \\
\hline Customers or buyers in the private sector & 7,7 & 7,8 & 5,6 & 13,0 & 9,7 & 5,7 \\
\hline Competitors or other businesses in the same sector & 2,6 & 2,0 & 2,6 & 8,5 & 1,8 & 3,5 \\
\hline Consultants, commercial laboratories & 4,6 & 4,7 & 3,3 & 7,6 & 6,6 & 2,5 \\
\hline Universities or other higher institutions & 9,1 & 10,7 & 4,0 & 8,1 & 11,3 & 6,8 \\
\hline Public administration, public research institutes & 4,9 & 5,4 & 2,2 & 8,1 & 5,0 & 4.7 \\
\hline Private research institutes & 3,7 & 3,9 & 2,8 & 4,9 & 3,7 & 3,8 \\
\hline
\end{tabular}

\section{Conclusion}

According to the European regulation on innovation statistics, the scope of statistical research on innovation is represented by the total population of enterprises that carry out activities in industry and services. The National Institute of Statistics provides the necessary means for carrying out statistical research on innovation in businesses in the business and industrial environment. The companies were selected according to their size (according to the number of employees). The size of the company is evaluated according to the criterion of the average number of employees, during the reference period. In accordance with the criteria issued by EUROSTAT, the delimitation of the companies is carried out in the following intervals:- small businesses: 10- 49 employees; - medium enterprises: 50-249 employees; - large enterprises: 250 employees and over.

The statistical unit used was the enterprise, defined as a grouping of legal units that is constituted as an organizational entity for the production of goods, commercial services, or services of social interest, which benefit from a decision autonomy, especially to ensure its current resources. An enterprise carries out one or more activities, in one or more places (local headquarters). The selected companies have legal personality and carry out activity in the industry and part of the services, according to the scope of the statistical research.

\section{Acknowledgements}

This work is supported by project POCU 125040, entitled "Development of the tertiary university education to support the economic growth - PROGRESSIO", co-financed by the European Social Fund under the Human Capital Operational Program 2014-2020.

\section{References}

Altenburg, T., \& Meyer-Stamer, J. (1999). How to promote clusters: policy experiences from Latin America.World Development, 27 (9), 1693-1713.

Asheim, B., Martin, P., \& Cooke, R. (2006). Clusters and regional development. Critical reflections and explorations. London, New York: Routledge.

Asheim, B., \& Gertler, M. (2005). The geography of innovation. Oxford: Oxford University Press. In Fagerberg, J., Mowery, D.C. (Eds.).The Oxford Handbook of Innovation (pp. 291-317). Oxford: Oxford University Press.

Audretsch, D.B., \& Feldman, M.P. (1996). R\&D spillovers and the geography of innovation and production. American Economic Review, 86, 253-273.

Bathelt, H., \& Glückler, J. (2002). Economic geography. Economic relationships from a spatial perspective. Stuttgart: Verlag Eugen Ulmer.

Bejinaru, R. (2017). Knowledge strategies aiming to improve the intellectual capital of universities. Management \& Marketing. Challenges for the Knowledge Society, 12(3), 500-523. 
Bejinaru, R., \& Prelipcean, G. (2017). Successful strategies to be learnt from world-class universities.Management \& Marketing. Challenges for the Knowledge Society, 11(1), 350-358.

Bejinaru, R., \& Hapenciuc, C.V. (2016). Valorization of the learning organization's principles in the business HESIn Bratianu, C.,Zbuchea, A., Pinzaru, F., Vatamanescu, E.-M., Leon, R.D. (Eds.). Strategica -International Conference - Fourth Edition, "Local versus Global PICBE | 1068 - Opportunities and Risks in the Contemporary Business Environment (pp. 600-611). Bucharest: Tritonic.Bejinaru, R., \& Iordache, S. (2010). Knowledge channeling in the learning organization. In Bratianu, C., Lixandroiu, D. (Eds.). Proceedings of the $5^{\text {th }}$ International Conference on Business Excellence (pp.59-62).Infomarket.

Blien, U., \& Maier, G. (2008). The economics of regional clusters. Networks, technology and policy. Cheltenham: Edward Elgar.

Boja, C. (2011). Clusters models, factors and characteristics. International Journal of Economic Practices and Theories, 1 (1), 34-43.

Bortagaray, I., \& Tiffin, S., (2005). Innovation clusters in Latin America (2005). Learning and Knowledge for the Network Society Retrieved from https://ssrn.com/abstract=1497732.

Bratianu, C. (2018). Intellectual capital research and practice: 7 myths and one golden rule. Management \& Marketing. Challenges for the Knowledge Society, 13(2), 859-879.

Bratianu, C., \& Bejinaru, R. (2019). The theory of knowledge fields: a thermodynamics approach. Systems, 7, 20.

Bratianu, C., \& Bejinaru, R. (2020). Knowledge dynamics: a thermodynamics approach. Kybernetes, 49(1), 6-21.

Bratianu, C., Vasilache, S., \& Jianu, I. (2006). Business Management. Bucharest: Editura ASE.

Bratianu, C., Agapie, A., \& Orzea, I. (2011). Knowledge dynamics modeling using Analytic Hierarchy Process (AHP). In Turner, G., Minnone, C. (Eds.). Proceedings of the $3^{\text {rd }}$ European Conference on Intellectual Capital (pp.94-102). Reading: Academic Conferences and Publishing International. Bratianu, C., \& Vatamanescu, E.M. (2017). Students perception on developing conceptual generic skills for business: a knowledgebased approach. VINE Journal of Information and Knowledge Management Systems, 47(4), Special Issue, 490-505.

Christensen, T. A., Lämmer-Gamp, T., \& Köcher, G. M. (2012). Let's make a perfect cluster policy and cluster programme. Smart recommendations for policy makers. Berlin, Copenhagen: Innovation + Technik GmbH.

Dima, A.M., Hadad, S., \& Luchian, I. (2017). Review on the dimensions of business-university alliances. In Dima. A.M. (Ed.). Proceedings of the $11^{\text {th }}$ International conference on Business excellence (pp. 64-73). De Gruyter.Dima, A.M., Hadad, S., \& Cantaragiu, R. (2016). A conceptual analysis of business-university knowledge transfer in the energy field. In Tantau, A., Dima, A.M., Hadad, S. (Eds.). Proceedings of the $10^{\text {th }}$ International Conference on Business excellence. Energy, climate change, and sustainability (pp. 199205). Bucharest: Business Excellence.

Duque, J. C., Rey, S. J., \& Gomez, D. A. (2010). Identifying industry clusters in Colombia based on graph theory. Ensayos Sobre Poitica Economica, 59, 14-45.

Feser, E. (1998). Old and new theories of industry clusters. In Steiner, M. (Ed.). Clusters and regional specialization (pp.18-40). London: Pion Limited.

Genosko, J. (2006). Cluster development in Bavaria - problems and perspectives of implementation. In H. Pechlaner, E. Fischer, E.-M. Hammann (Eds.). Location 
competition and tourism. Regional strategies for success (pp.61-76). Berlin: Schmidt Verlag.

Gulati, M., \& Dhanda,C. (1997). Preliminary status report on knitwear industry of Ludhiana Mime of UNIDO. New Delhi.

Hadad, S. (2018). The geographic distribution of Knowledge Economy (KE) within the European Union (EU). Management \& Marketing-Challenges For The Knowledge Society, 13(3), 1089-1107.

Hapenciuc, C.V., Bejinaru, R., Roman, C., \& Neamtu, D.M. (2016). The role of HES within the evolution of the business sector. In Gómez Chova, L., López Martínez, A., Candel Torres (Eds.). EDULEARN 16 Proceedings - 8th annual International Conference on Education and New Learning Technologies (pp.5309-5314).Valencia: IATED. Malmberg, A., \& Power, D. (2006). True clusters. A severe case of conceptional headache. In Asheim, B., Cooke, P., Martin, R. (Eds.). Clusters and regional development. Critical reflections and explorations(pp.50-68). London, New York: Routledge.

Neamtu, D., Hapenciuc, V., \& Bejinaru, R. (2019). The impact of digitalization on business sector development in the knowledge economy, In A. Dima \& S. Hadad (Eds.), Proceedings of the International Conference on Business Excellence (pp.479-491). Sciendo., Bucharest, Romania, 13(1), pp. 479-491.

Passiante, G., \& Secundo, G. (2002). From geographical innovation clusters towards virtual innovation clusters: the Innovation Virtual System. Retrieved from http://www.raumplanung.tu- dortmund.de/rwp/ersa2002/en/documents/ ersa2002papers_savedir/270.pdf.

Perlik, M., \& Messerli, P. (2001). Newer approaches to regional development and their implementation in national and international development programs. Geographisches Institut Universität Bern. Bern.

Porter, M. (1998a). On competition. Boston: Harward Business School Press.

Porter, M. (1998b). The competitive advantage of nations: with a new introduction. New York: Free Press.

Porter, M. (2000). Location, competition and economic development: Local clusters in a global economy. Economic Development Quarterly, 14(1), 15-20.

Prelipcean, G., \& Bejinaru, R. (2018). University agenda for developing students' skills in the knowledge economy. In Brătianu, C., Zbuchea, A., Vitelar, A. (Eds.). StrategicaInternational Conference - Sixth Edition "Challenging the Status Quo in Management and Economics"(pp.600-610).Bucharest: Tritonic.

Sandee, H. (1995). Innovation adoption in rural industry-Technological change in roof tile clusters in central Java, Indonesia. Doctoral Thesis, Free University, Amsterdam.

Schätzl, L. (2001). Economic geography 1st theory. Paderborn, München, Wien, Zürich: Ferdinand Schöning.

Schmitz, H., \& Nadvi, K.(1999). Clustering and industrialization: introduction.World Development, 27(9), 1503-1514.

Sölvell, Ö. (2008). Clusters. Balancing evolutionary and constructive forces. Stockholm: Ivory Tower Publishers.

World Bank (2014). Glossary. Retrieved from

http://www.worldbank.org/depweb/english/modules/glossary.html. 
Wrobel, M. (2008). Clusters and networks ... their spell has by no means been broken!. In Blien, U., Maier, G. (Eds.). The economics of regional clusters. networks, technology and policy (pp.235-264). Cheltenham: Edward Elgar.

*** Innovative Regional Cluster of North-East Molecular and Structural Imagistics.

PICBE $\mid 1070$ 